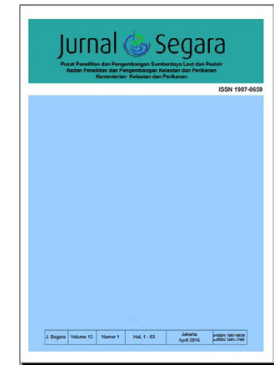

JURNAL SEGARA

http://ejournal-balitbang.kkp.go.id/index.php/segara

ISSN : 1907-0659

e-ISSN : 2461-1166

Nomor Akreditasi: 766/AU3/P2MI-LIPI/10/2016

\title{
KONDISI HIDROOSEANOGRAFI PERAIRAN DAN HUBUNGANNYA DENGAN KELIMPAHAN FITOPLANKTON DI PERAIRAN SEDANAU DAN PULAU TIGA, KABUPATEN NATUNA, KEPULAUAN RIAU
}

\section{HYDRO-OCEANOGRAPHIC CONDITION AND ITS RELATIONSHIP \\ WITH PHYTOPLANKTON ABUNDANCE AT SEDANAU AND TIGA ISLAND ADJACENT WATER, NATUNA REGENCY, RIAU ISLAND}

\author{
( Nyoman Radiarta1), Erlania ${ }^{2)}$ \& Joni Haryadi ${ }^{3)}$ \\ 1)Balai Riset dan Observasi Laut, BRSDMKP-KKP, Bali \\ ${ }^{2)}$ Pusat Riset Perikanan, BRSDMKP-KKP, Jakarta \\ ${ }^{3)}$ Balai Riset Pemulihan dan Konservasi Sumber Daya Ikan, BRSDMKP-KKP, Purwakarta \\ Diterima: 7 Maret 2017 ; Diterima Setelah Perbaikan: 12 Desember 2017 ; Disetujui Terbit: 20 Desember 2017
}

\begin{abstract}
ABSTRAK
Penelitian ini bertujuan untuk mengkaji kondisi kualitas perairan dan hubungannya dengan kondisi fitoplankton di perairan Pulau Sedanau dan Pulau Tiga Kabupaten Natuna, Kepulauan Riau. Kondisi kualitas perairan dianalisis secara statistik dengan pendekatan klaster analisis dan indeks kualitas air/WQI (Water Quality Index), dengan melibatkan seluruh parameter dan berdasarkan parameter kunci biota perairan. Hasil analisis klaster membagi kawasan perairan menjadi tiga klaster di masing-masing lokasi penelitian. Klaster ini membagi kawasan perairan berdasarkan kedekatan dengan daratan dan tingkat keterbukaan (keterlindungan) kawasan. Pembagian kawasan ini dapat digunakan sebagai acuan lokasi pengembangan budi daya laut. Analisa indeks kualitas air menunjukkan bahwa perairan Pulau Sedanau dan Pulau Tiga masih dalam kategori baik dengan nilai indeks berkisar antara 71-90. Terdapat hubungan yang signifikan (90\%) antara klaster kawasan dengan kondisi fitoplankton, sedangkan hubungannya dengan WQI umumnya tidak signifikan. Hasil penelitian ini menunjukkan bahwa karaktersitik perairan di Pulau Sedanau dan Pulau Tiga cukup berbeda, namun masih sangat baik untuk mendukung pengembangan budi daya laut.
\end{abstract}

Kata kunci : Kualitas air, analisa klaster, indeks kualitas air, budi daya laut, Natuna.

\begin{abstract}
The aim of the study was to assess water quality condition and its relation to phytoplankton ecology condition in the adjacent waters of Sedanau and Pulau Tiga in the Natuna Regency, Province of Riau Islands. Water quality conditions were analyzed statistically using the cluster analysis and water quality index I WQI (index based on all the parameters and on the basis of key parameters of aquatic biota). The results of cluster analysis were clasified the waters into three clusters at each study site. These classifications were based on its position relative to the mainland and the level of sheltered areas. The cluster area can be used as a reference for site selection for marine aquaculture development. Analysis of water quality index shows that the adjacent waters of Sedanau and Pulau Tiga are still in good condition with index values range from 71 to 90 . There was a significant correlation (90\%) between cluster areas and phytoplankton, while generaly no correlation with WQI. The results of the study indicates that the characteristics waters of Sedanau and Pulau Tiga are quite different, but still very good to support the development of marine aquaculture.
\end{abstract}

Keywords: Water quality, cluster analysis, water quality index, mariculture, Natuna.

Corresponding author:

JI. Pasir Putih II Ancol Timur, Jakarta Utara 14430. Email: radiarta@yahoo.com 


\section{PENDAHULUAN}

Kabupaten Natuna merupakan daerah tingkat II yang wilayahnya terdiri dari banyak pulau-pulau kecil. Kabupaten Natuna yang terbentuk pada 1999 sesuai dengan UU Nomor 53 tahun 1999 yang memiliki total luas wilayah mencapai $3.492 \mathrm{~km}^{2}$ dengan persentase $97 \%$ merupakan wilayah laut dan $3 \%$ wilayah daratan (DKP Natuna, 2011). Dengan karakteristik tersebut, maka potensi kelautan dan perikanan Kabupaten Natuna sangat besar untuk dikembangkan dan dimanfaatkan. Berdasarkan kajian Pengembangan Kawasan Kelautan dan Perikanan Terintegrasi (PK2PT) oleh Direktorat Jenderal Kelautan, Pesisir dan Pulau-Pulau Kecil (Ditjen KP3K, 2015), pengembangan budi daya laut meliputi budi daya rumput laut dan ikan laut dengan Keramba Jaring Tancap (KJT) dan Keramba Jaring Apung (KJA) di Kabupaten Natuna meliputi Kecamatan Bunguran Barat dan Kecamatan Pulau Tiga. Bahkan Kecamatan Pulau Tiga diusulkan sebagai sentra PK2PT yang terbagi menjadi empat zona yaitu zona pusat PK2PT, zona sentra perikanan I, zona sentra perikanan II, dan zona sentra perikanan III. Untuk mendukung penetapan kawasan tersebut, ketersediaan data dan informasi detail masing-masing kawasan sangat diperlukan, yang meliputi kondisi kualitas perairan, kelayakan lahan pengembangan marikultur, eksisting marikultur yang berkembang, dan sosial ekonomi serta pola pemasaran hasil marikultur.

Kualitas air adalah faktor penting yang menjadi perhatian dalam pengembangan budi daya laut. Oleh karena itu pemantauan secara berkelanjutan perlu dilakukan untuk menghasilkan estimasi kondisi kualitas perairan secara representatif dan komprehensif (Butler et al., 2001) serta mengetahui kondisi ataupun kecenderungan perubahan yang terjadi. Tersedianya data kualitas air yang komplek meliputi parameter fisik, kimia, biologi (plankton), dan ekologi kawasan, tentunya harus didukung dengan tahapan analisis yang baik. Oleh karena itu, langkah analisis berupa klasifikasi, pemodelan, dan interpretasi pemantauan data kualitas air merupakan tahapan penting dalam penilaian kualitas air. Sehubungan dengan pemantauan kualitas air untuk biota laut, Kementerian Lingkungan Hidup telah menetapkan baku mutu air laut untuk biota laut melalui KepMen No.51 tahun 2004 (KLH, 2004). Acuan tersebut digunakan sebagai standar baku mutu kualitas air laut untuk mendukung budi daya biota laut.

Beberapa metode analisis kualitas air yang dapat dilakukan adalah melalui analisis sederhana dengan hanya membandingkan nilai yang diperoleh dengan standar baku mutu atau melalui analisis statistik dan pemodelan yang komplek. Multivariat analisis menggunakan analisis klaster telah banyak diaplikasikan dalam pemantuan kualitas air (Phung et al., 2015; Bayo \& opez-Castellanos, 2016). Tujuan utama analisis ini untuk mengelompokkan suatu kawasan sesuai dengan karakteristik data yang ada, sehingga nantinya dapat diambil langkah-langkah strategis sesuai dengan pembagian kawasan tersebut. Analisis lainnya yang dapat digunakan adalah indeks kualitas air (water quality index-WQI). WQI bertujuan untuk menghasilkan satu nilai kualitas air tanpa satuan dengan cara mengkombinasikan berbagai parameter (fisik dan kimia) yang memiliki satuan yang berbeda melalui tahapan normalisasi serta pembobotan (Abbasi \& Abbasi, 2012). WQI telah banyak diaplikasikan bagi penelitian kualitas air untuk berbagai kepentingan diantaranya akuakultur (Simões et al., 2008), antropologi (Kannel et al., 2007), dan pemantauan kondisi perairan (Lobata et al., 2015). Hubungan antara kondisi perairan yang meliputi parameter fisik dan kimia dengan kondisi biologi (fitoplankton) juga telah menjadi perhatian dalam pemanfaatan kawasan khususnya untuk akuakultur. Korelasi antara kondisi fitoplankton dengan parameter kunci kualitas perairan seperti suhu, kecerahan, nitrat dan fosfat telah banyak dibahas (Gao \& Song, 2005; Mujiyanto et al., 2011), namun hubungan antara kondisi perairan yang ditampilkan dalam analisis klaster dan WQI dengan kondisi fitoplankton secara spesifik belum digali secara mendalam.

Hipotesa dari penelitian ini adalah kawasan perairan laut di lokasi penelitian akan dikelompokkan karakteristiknya berdasarkan lokasi kedekatannya terhadap daratan dan tingkat keterbukaan (keterlindungan) kawasan, sehingga nantinya dapat diidentifikasi parameter lingkungan perairan melalui penghitungan indeks (WQI) yang memberikan peran utama dalam karakteristik kawasan tersebut serta dikaitkan dengan kondisi fitoplankton dan pengembangan budi daya laut. Penelitian ini bertujuan untuk mengkaji kondisi kualitas perairan dan hubungannya dengan kondisi fitoplankton di perairan Pulau Sedanau dan Pulau Tiga Kabupaten Natuna, Kepulauan Riau. Dalam penelitian ini kondisi kualitas perairan dianalisis melalui pendekatan analisis klaster dan WQI. Hasil dari penelitian ini diharapkan dapat memberikan gambaran tentang karakteristik perairan sebagai kawasan minapolitan di Kabupaten Natuna.

\section{METODE PENELITIAN}

\section{Lokasi Penelitian}

Penelitian telah dilakukan di Kabupaten Natuna Provinsi Kepulauan Riau (Gambar 1). Kabupaten Natuna merupakan satu dari lima lokasi PK2PT lingkaran emas ekonomi maritim Indonesia. Kabupaten ini mempunyai kawasan pesisir berupa teluk dan pulau-pulau kecil yang sangat berpotensi untuk pengembangan budi daya laut diantaranya di 


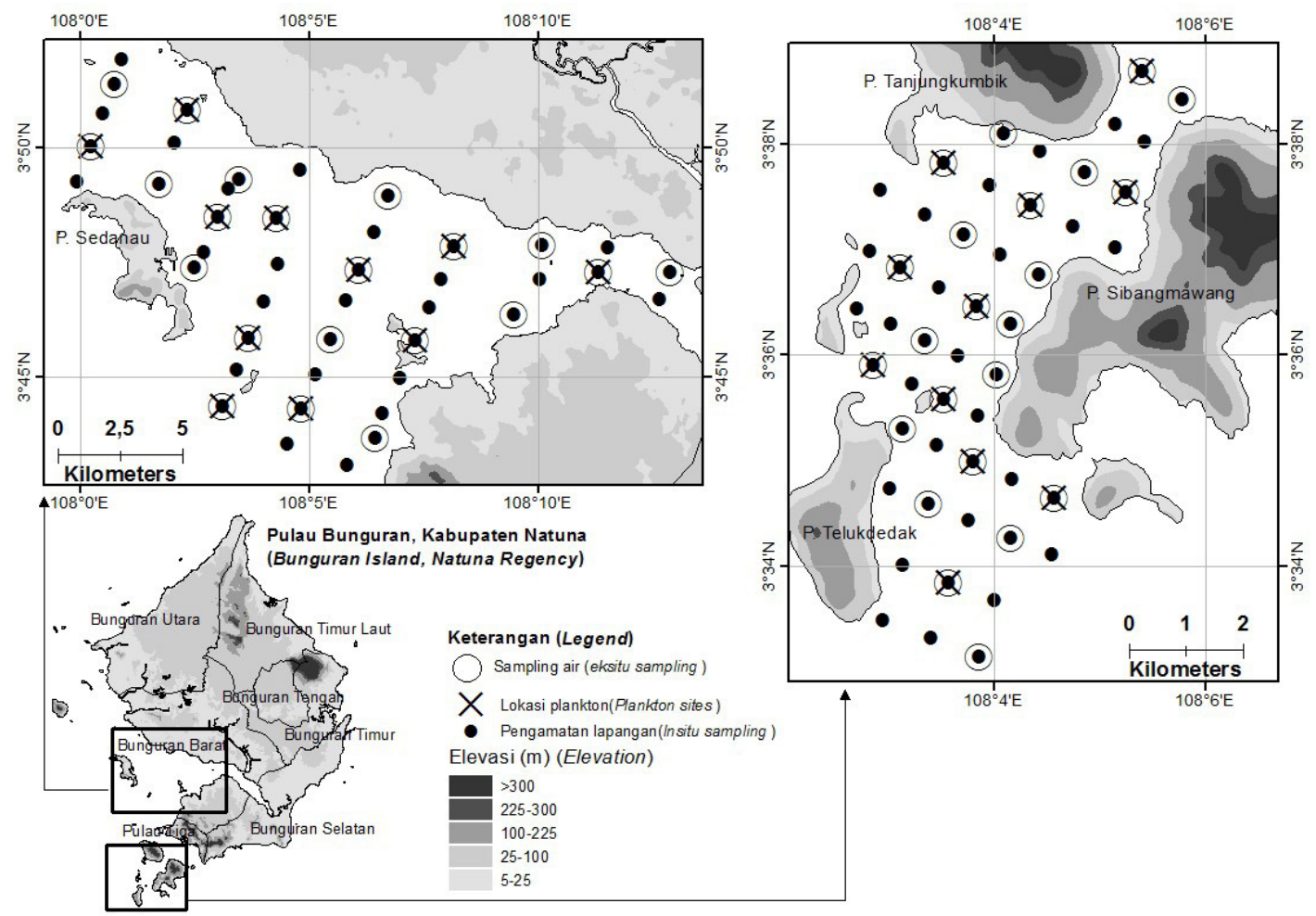

Gambar 1. Lokasi penelitian dan distribusi titik pengamatan kualitas air di Perairan Sedanau dan Pulau Tiga Kabupaten Natuna, Kepulauan Riau.

Kecamatan Bunguran Barat dan Kecamatan Pulau Tiga (Gambar 1; DKP Natuna, 2011).

\section{Pengumpulan Data}

Pengumpulan data kualitas perairan dilakukan pada Musim Barat (Desember 2015). Data yang dikumpulkan meliputi parameter fisik, kimia, dan biologi. Stasiun pengumpulan data kualitas air dirancang dengan sistem informasi geografis (SIG) menggunakan teknik acak terstruktur (systematic random sampling) (Clark \& Hosking, 1986). Pengukuran kualitas perairan di lapangan (in situ) menggunakan multi-parameter water quality checker Horiba U-50. Total titik pengamatan yang dikumpulkan adalah 91 dengan rincian masing-masing lokasi yaitu 43 titik di perairan Pulau Sedanau dan 48 titik di perairan Pulau Tiga (Gambar 1). Pameter in situ yang diukur meliputi suhu, pH, kekeruhan, dan oksigen terlarut (DO). Pengambilan contoh air juga dilakukan untuk dianalisis parameter kimia dan biologi. Jumlah titik pegamatan untuk kimia adalah 20 titik di perairan Pulau Sedanau dan 23 titik di perairan Pulau Tiga, sedangkan untuk parameter biologi dikumpulkan sebanyak 11 titik di masing-masing lokasi penelitian (Gambar 1). Analisis air ini dilakukan di Laboratorium Produktivitas dan Lingkungan Perairan (PROLING) Fakultas Perikanan dan IImu Kelautan IPB, Bogor. Parameter kimia yang dianalisis meliputi: biochemical oxygen demand/ $\mathrm{BOD}_{5}$, $\mathrm{N}$ total, nitrat $\left(\mathrm{NO}_{3} \mathrm{~N}\right)$, amonium $\left(\mathrm{NH}_{4} \mathrm{~N}\right), \mathrm{P}$ total, dan ortofosfat $\left(\mathrm{PO}_{4} \mathrm{P}\right)$. Sedangkan parameter biologi yang dianalisis adalah fitoplankton. Pengambilan contoh air untuk parameter biologi (fitoplankton) dilakukan secara vertikal, kemudian disaring dengan menggunakan plankton net no.25 dengan ukuran mata jaring $64 \mu \mathrm{m}$ (Nontji, 2008). Contoh air kemudian diawetkan dengan dengan lugol $1 \mathrm{ml} / 100 \mathrm{ml}$. Metode pengambilan, preservasi, dan analisis contoh air mengacu pada metode standar APHA (2012).

\section{Analisa Data}

Data yang dikumpulkan pada penelitian ini dianalisis dengan beberapa pendekatan yaitu statistik multivariat menggunakan analisis klaster (cluster analysis/CA), indeks kualitas air (water quality indexWQI), dan kondisi fitoplankton.

Cluster analysis (CA) digunakan untuk mengklasifikasikan kawasan perairan berdasarkan stasiun pengamatan yang memiliki kesamaan karakteristik objek, sehingga objek yang serupa akan dikelompokkan dalam klaster yang sama sesuai dengan kriteria yang digunakan (Kamble \& Vijay, 2011; Bayo \& opez-Castellanos, 2016). CA dilakukan pada data yang telah distandarisasi melalui transformasi skala-Z (Z-scale). Metode CA yang digunakan dalam penelitian ini adalah Agglomerative hierarchical clustering (AHC) dengan metode Ward (Ward's method) dan Euclidean distances untuk mengukur tingkat kesamaan objek (Razmkhah et al., 2010; Phung et al., 2015). Hasil CA digambarkan dalam bentuk 
Tabel 1.

Faktor normalisasi dan bobot relatif dari parameter kualitas air

\begin{tabular}{|c|c|c|c|c|c|c|c|c|c|c|c|c|}
\hline \multirow[t]{2}{*}{ Variabel } & \multicolumn{4}{|l|}{ Bobot relatif } & \multicolumn{8}{|c|}{ Faktor Normalisasi (Ci) } \\
\hline & $\overline{(P I)}$ & 100 & 90 & 80 & 70 & 60 & 50 & 40 & 30 & 20 & 10 & 0 \\
\hline Suh & 1 & $21 / 16$ & $22 / 15$ & $24 / 14$ & $26 / 12$ & $28 / 10$ & $30 / 5$ & $32 / 0$ & $36 /-2$ & $40 /-4$ & $45 /-6$ & $45 /<-6$ \\
\hline $\mathrm{pH}$ & 1 & 7 & $7-8$ & $7-8,5$ & $7-9$ & $6,5-7$ & $6-9,5$ & $5-10$ & $4-11$ & $3-12$ & $2-13$ & $1-14$ \\
\hline Kekeruhan (turbidity) & 2 & $<5$ & $<10$ & $<15$ & $<20$ & $<25$ & $<30$ & $<40$ & $<60$ & $<80$ & $\leq 100$ & $>100$ \\
\hline DO (dissolved oxygen) & 4 & $\geq 7,5$ & $>7$ & $>6,5$ & $>6$ & $>5$ & $>4$ & $>3,5$ & $>3$ & 2 & $\leq 1$ & $<1$ \\
\hline $\mathrm{BOD}_{5}$ & 3 & $<0,5$ & $<2$ & $<3$ & $<4$ & $<5$ & $<6$ & $<8$ & $<10$ & $<12$ & $\leq 15$ & $>15$ \\
\hline $\mathrm{NH}_{4}$ (ammoium) & 3 & $<0,01$ & $<0,05$ & $<0,1$ & $<0,2$ & $<0,3$ & $<0,4$ & $<0,5$ & $<0,75$ & $<1$ & $\leq 1,25$ & $>1,25$ \\
\hline $\mathrm{NO}_{3}^{4}$ (nitrate) & 2 & $<0,5$ & $<2$ & $<4$ & $<6$ & $<8$ & $<10$ & $<15$ & $<20$ & $<50$ & $\leq 100$ & $>100$ \\
\hline P total (total phosphate) & 1 & $<0,2$ & $<1,6$ & $<3,2$ & $<6,4$ & $<9,6$ & $<16$ & $<32$ & $<64$ & $<96$ & $\leq 160$ & $>160$ \\
\hline thophosphate) & 1 & $<0,025$ & $<0,05$ & $<0,1$ & $<0,2$ & $<0,3$ & $<0,5$ & $<0,75$ & $<1$ & $<1,5$ & $\leq 2$ & $>2$ \\
\hline $\mathrm{N}$ total (total nitrogen) & 2 & $<0,8$ & $<3,8$ & $<7,5$ & $<13$ & $<18$ & $<27$ & $<48$ & $<85$ & $<149$ & $\leq 265$ & $>265$ \\
\hline
\end{tabular}

dendogram (diagram pohon), dan peta sebaran spasial pengelompokkan kawasan. Analsis CA menggunakan XLSTAT addinsoft dalam Microsoft Excel.

Indeks kualitas perairan (WQI) dianalisis berdasarkan dua pendekatan yaitu WQI objektif WQI $_{\text {obj }}$ (perhitungan terhadap seluruh parameter kualitas air yang dikumpulkan) dan WQI minimum $W_{\text {min }}$ (perhitungan berdasarkan parameter kunci biota budi daya). Tahapan normalisasi dilakukan sebelum perhitungan WQI. Normalisasi merupakan tahapan untuk melakukan standarisasi terhadap seluruh parameter yang memiliki satuan yang beragam menjadi nilai tanpa satuan (Kannel et al., 2007; Koçer et al., 2014). Hal ini dilakukan melalui tranformasi nilai seluruh parameter menjadi skala dengan kisaran dari 0-100 (Tabel 1).

Data hasil normalisasi kemudian digunakan

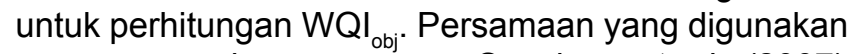
mengacu pada persamaan Sanchez et al. (2007), yaitu:

$$
\mathrm{WQI}_{o b j}=\frac{\sum_{i=1}^{n} C_{i} P_{i}}{\sum_{i=1}^{n} P_{i}}
$$

di mana, $\mathrm{n}$ adalah jumlah total parameter kualitas perairan, $\mathrm{Ci}$ adalah nilai yang diberikan untuk tiap parameter setelah proses normalisasi (0 - 100), dan Pi adalah bobot relatif yang diberikan untuk tiap parameter dengan nilai antara 1 - 4, berdasarkan tingkat kepentingan parameter tersebut terhadap organisme akuatik (Tabel 1; Kannel et al., 2007). Parameter yang digunakan untuk menghitung $\mathrm{WQI}_{\text {obj }}$ yaitu: suhu, $\mathrm{pH}$, kekeruhan, DO, $\mathrm{BOD}_{5}, \mathrm{~N}$ total, $\mathrm{NO}_{3-} \mathrm{N}, \mathrm{NH}_{4}, \mathrm{P}$ total, dan $\mathrm{PO}_{4-} \mathrm{P}$.

Selain itu, perhitungan $\mathrm{WQI}_{\min }$ juga dilakukan terhadap parameter penting yang berpengaruh terhadap biota budi daya. Kannel et al. (2007) menggunakan lima parameter yaitu DO, suhu, pH, konduktivitas, dan TSS.; sedangkan Simões et al. (2008) hanya mengunakan tiga parameter penting untuk mengkaji kondisi perairan bagi aktivitas budi daya perikanan yaitu DO, kekeruhan, dan P total. Pada penelitian ini perhitungan $\mathrm{WQI}_{\text {min }}$ mengunakan lima parameter yaitu suhu, $\mathrm{pH}$, kekeruhan, $\mathrm{DO}, \mathrm{NH}_{4}$. Lima parameter yang digunakan ini merupakan parameter kunci yang mewakili karakteristik fisik, kimia, dan nutrien perairan yang dapat berfluktuasi dan mempengaruhi perkembangan biota budi daya (SimÕes et al., 2008; Radiarta \& Erlania, 2015). WQImin dihitung dengan persamaan (Kannel et al., 2007; Simões et al., 2008):

$$
\mathrm{WQI}_{\min }=\frac{\sum_{i=1}^{5} C_{i}}{5}
$$

Berdasarkan nilai kalkulasi WQI, selanjutnya kualitas perairan dapat diklasifikasikan menjadi lima kelas, yaitu: sangat baik $(91-100)$, baik $(71-90)$, sedang (51 - 70), buruk (26 - 50), dan sangat buruk (0 - 25) (Kannel et al., 2007; Koçer et al., 2014).

Analisa kondisi fitoplankton dalam penelitian ini meliputi kelimpahan, jumlah jenis, dan indeks biologinya (Odum, 1971). Perhitungan kelimpahan fitoplankton dilakukan menggunakan alat bantu Sedwick Rafter Counter (SRC) yang dilihat menggunakan alat bantu mikroskop (APHA, 1989), dan dihitung dalam ind/L.

Hasil analisis data yang meliputi CA, WQI ${ }_{\text {obj' }}$ $\mathrm{WQI}_{\min }$, dan kondisi fitoplankton juga dianalisis secara spasial melalui interpolasi dengan teknik inverse distance weighted (IDW) (Johnson \& McChow, 2001), yang terdapat dalam perangkat lunak ArcGIS v.10.3 (The Environmental System Research Institute (ESRI), USA). Hubungan CA, WQI dan kondisi (kelimpahan dan indeks biologi) fitoplankton dianalisis menggunakan korelasi Spearman pada tingkat kepercayaan 90\% $(\alpha=0,10)$. 


\section{HASIL DAN PEMBAHASAN}

\section{Kondisi Kualitas Perairan}

Kabupaten Natuna memiliki potensi laut yang sangat besar untuk pengembangan aktivitas perikanan, termasuk budi daya. Pada kawasan perairan Natuna banyak ditemukan berbagai jenis ikan-ikan karang seperti kerapu dan napoleon. Hal ini merupakan indikasi awal bahwa karakterisitik kawasan tersebut sesuai untuk pengembangan aktivitas budi daya ikan laut. Secara umum kondisi perairan di Pulau Tiga dan Pulau Sedanau tergolong baik dan dapat dimanfaatkan untuk aktivitas budi daya laut. Kedua kawasan perairan tersebut memiliki karakteristik yang cukup berbeda; perairan Pulau Tiga umumnya memiliki tingkat kecerahan yang tinggi, dan sebaliknya perairan Pulau Sedanau memiliki tingkat kecerahan yang cukup rendah (Rahayu et al., 2016). Kondisi ini akan sangat berpengaruh terhadap penentuan kawasan untuk pengembangan aktivitas budi daya dan pemilihan komoditas yang akan dikembangkan. Tabel 2 menyajikan kisaran nilai kondisi kualitas perairan di perairan Sedanau dan Pulau Tiga, Natuna.

Kawasan perairan Pulau Sedanau terdapat area perairan yang memiliki kekeruhan tinggi, dengan nilai turbiditas mencapai 3,90 NTU (Tabel 2). Hal ini disebabkan karena pada area tersebut mendapat pengaruh dari masukan air tawar yang berasal dari sungai yang bermuara pada lokasi tersebut (Gambar 1) dan membawa masukan bahan organik tinggi dari kawasan hutan mangrove. Selain itu, pada lokasi tersebut juga terdapat jalur transportasi kapal antara Pulau Sedanau dan Pulau Bunguran. Tingginya nilai turbiditas di kawasan perairan Pulau Sedanau juga ditunjukkan oleh tingginya nilai BOD yaitu berkisar 1,9 - 3,6 mg/L yang memperlihatkan bahwa konsentrasi bahan organik di perairan juga cukup tinggi. Namun kisaran nilai tersebut masih dibawah toleransi maksimum biota laut berdasarkan Kepmen-LH No. 51 Tahun 2004, yaitu 20 mg/L. Konsentrasi bahan organik dan konsentrasi nutrient terlarut yang cukup tinggi mengindikasikan kesuburan perairan yang tinggi (Tabel 2). Kondisi ini menunjukkan bahwa kawasan perairan tersebut berpotensi untuk pengembangan aktivitas budi daya rumput laut, teripang, dan jenis kekerangan. Ketiga komoditas tersebut merupakan spesies pengguna bahan organik terlarut di perairan.

Kisaran nilai hasil pengukuran parameter kualitas perairan pada kawasan perairan Pulau Tiga ditampilkan dalam Tabel 2. Secara umum beberapa parameter penting yang mendukung aktivitas budi daya laut seperti suhu dan DO tergolong baik untuk aktivitas budi daya ikan laut. Suhu perairan berkisar 29,02$30,02{ }^{\circ} \mathrm{C}$, rata-rata $29,43{ }^{\circ} \mathrm{C}$. Budi daya ikan kerapu dengan KJA sangat dipengaruhi oleh fluktuasi harian suhu perairan yang bersifat esktrim (Radiarta et al., 2014). Salah satu penyebab tingginya tingkat kematian ikan kerapu pada KJA di kawasan perairan Indonesia adalah perubahan suhu perairan yang umumnya terjadi dua kali dalam setahun, yaitu pada saat peralihan musim (Sadovy, 2000). Selain itu fluktuasi suhu yang konstrain dapat juga menyebabkan kematian ikan (Radiarta et al., 2014). Beberapa permasalahan yang umumnya dihadapi dalam budi daya ikan dengan KJA terkait dengan kondisi kualitas perairan, yaitu semakin menurunnya kualitas perairan di area sekitar KJA karena padat tebar ikan tinggi, terakumulasinya limbah budi daya di dasar perairan, over-feeding penggunaan pakan ikan rucah, blooming alga, serta sirkulasi air yang kurang baik karena pengaturan tata letak KJA yang kurang sesuai (Pomeroy et al., 2002). Kondisi perairan Pulau Tiga didominasi oleh dasar terumbu karang yang tersebar pada area-area yang relatif dangkal. Dari 48 titik pengamatan, hanya 21 titik yang memiliki kedalaman perairan lebih dari $10 \mathrm{~m}, 27$ titik lainnya hanya berkisar 1,5 - 8,0 m. Menurut Beveridge (2004), kedalaman perairan yang dapat dimanfaatkan untuk budi daya KJA bagi kebanyakan spesies ikan adalah sekitar $3-10 \mathrm{~m}$.

Tabel 2. Statistik deskriptif parameter kualitas perairan di Perairan Sedanau dan Pulau Tiga, Kabupaten Natuna Provinsi Kepulauan Riau

\begin{tabular}{llllllllll}
\hline Parameter & Unit & \multicolumn{3}{c}{ Perairan Sedanau } & \multicolumn{3}{c}{ Pulau Tiga } \\
\cline { 2 - 10 } & & $\mathbf{n}$ & Min & Max & Mean \pm SD & $\mathbf{n}$ & Min & Max & Mean \pm SD \\
\hline Suhu & ${ }^{\circ} \mathrm{C}$ & 43 & 28,32 & 31,04 & $29,75 \pm 0,43$ & 48 & 29,02 & 30,02 & $29,43 \pm 0,19$ \\
$\mathrm{pH}$ & & 43 & 8,55 & 9,01 & $8,69 \pm 0,12$ & 48 & 8,56 & 8,86 & $8,81 \pm 0,06$ \\
Kekeruhan & $\mathrm{NTU}$ & 43 & 0,00 & 3,90 & $0,19 \pm 0,70$ & 48 & 0,00 & 0,00 & $0,00 \pm 0,00$ \\
Oksigen (DO) & $\mathrm{mg} / \mathrm{L}$ & 43 & 4,34 & 8,31 & $5,85 \pm 0,84$ & 48 & 5,60 & 7,38 & $6,06 \pm 0,33$ \\
$\mathrm{BOD}_{5}$ & $\mathrm{mg} / \mathrm{L}$ & 21 & 1,90 & 3,60 & $2,60 \pm 0,74$ & 22 & 1,90 & 2,20 & $2,09 \pm 0,09$ \\
$\mathrm{NH}_{4}$ & $\mathrm{mg} / \mathrm{L}$ & 21 & 0,03 & 0,11 & $0,08 \pm 0,02$ & 22 & 0,02 & 0,09 & $0,06 \pm 0,02$ \\
$\mathrm{NO}_{3} \mathrm{~N}$ & $\mathrm{mg} / \mathrm{L}$ & 21 & 0,06 & 0,12 & $0,08 \pm 0,02$ & 22 & 0,05 & 0,08 & $0,06 \pm 0,01$ \\
Total P $_{\mathrm{PO}_{4} \mathrm{P}}$ & $\mathrm{mg} / \mathrm{L}$ & 21 & 0,10 & 0,14 & $0,11 \pm 0,01$ & 22 & 0,09 & 0,20 & $0,11 \pm 0,02$ \\
Total N & $\mathrm{mg} / \mathrm{L}$ & 21 & 0,03 & 0,06 & $0,04 \pm 0,01$ & 22 & 0,03 & 0,06 & $0,05 \pm 0,01$ \\
\hline
\end{tabular}



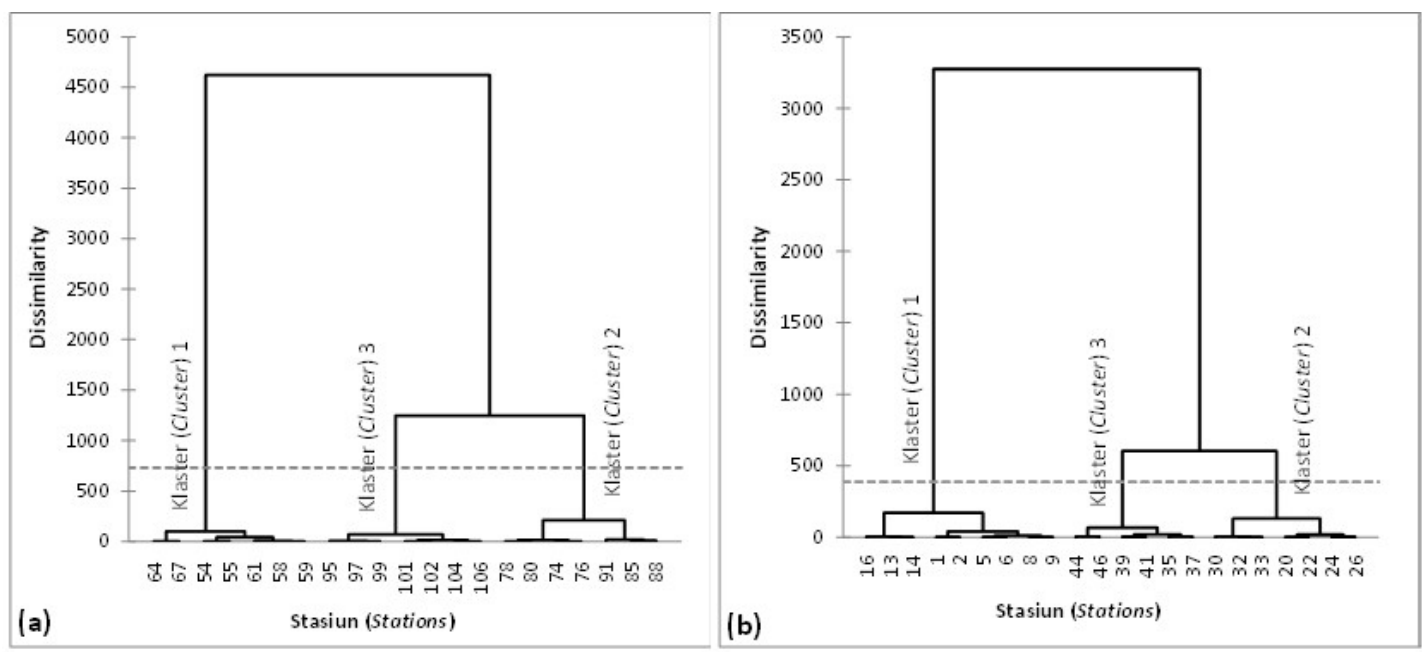

Gambar 2. Dendogram pengelompokkan stasiun pengamatan berdasarkan analisa klaster di perairan Sedanau (a) dan Pulau Tiga (b) Kabupaten Natuna.
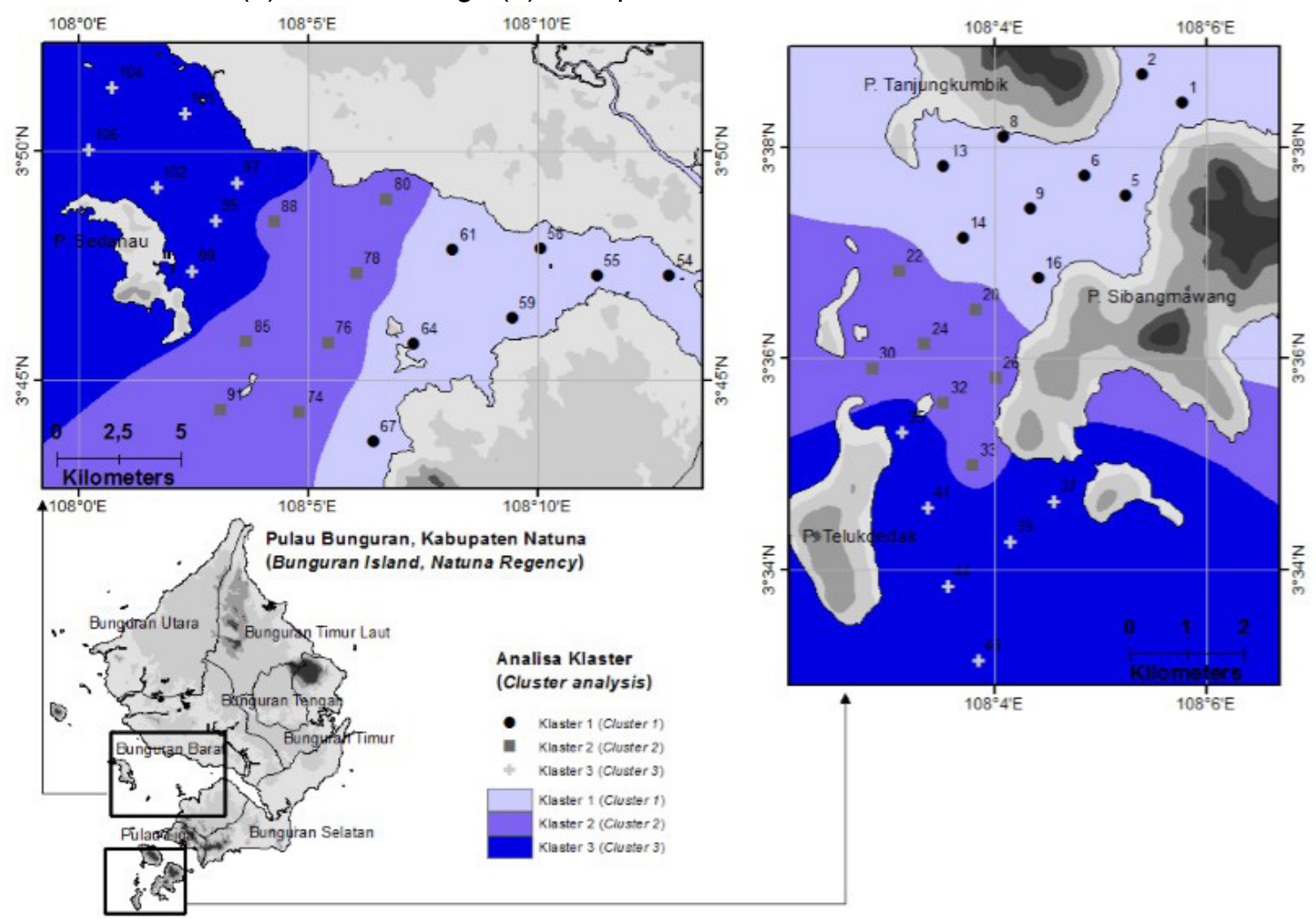

Gambar 3. Pembagian kawasan perairan berasarkan analisa kluster di Perairan Sedanau dan Pulau Tiga, Kabupaten Natuna Provinis Kepulauan Riau.

\section{Analisa Klaster}

Analisis klaster (CA) terhadap kondisi kualitas perairan baik secara spasial maupun temporal telah banyak diterapkan untuk melihat karakteristik suatu kawasan perairan (Kamble \& Vijay, 2011; Huang et al., 2011). CA dalam penelitian ini digunakan untuk mengklasifikasikan kawasan perairan secara spasial berdasarkan karakteristik kualitas perairan di masingmasing stasiun pengamatan, dan ditampilkan dalam bentuk histogram (Gambar 2) dan peta sebaran spasial (Gambar 3).
Secara spasial, CA mengelompokkan kawasan perairan menjadi tiga klaster yang berbeda untuk perairan Sedanau (Gambar 2a dan 3) dan Pulau Tiga (Gambar 2b dan 3). Secara umum hasil CA ini membagi kawasan perairan berdasarkan kedekatan dengan daratan dan tingkat keterbukaan (keterlindungan) kawasan. Kawasan dengan kategori klaster 1 terletak dekat dengan daratan dan terlindung dari laut lepas, sedangkan klaster 3 terletak di luar dan berhadapan langsung dengan laut lepas. Konsentrasi nutrien perairan ( $\mathrm{N}$ total, nitrat, dan amonium) merupakan parameter penciri utama yang membedakan klaster di kedua lokasi perairan tersebut. Konsentrasi 

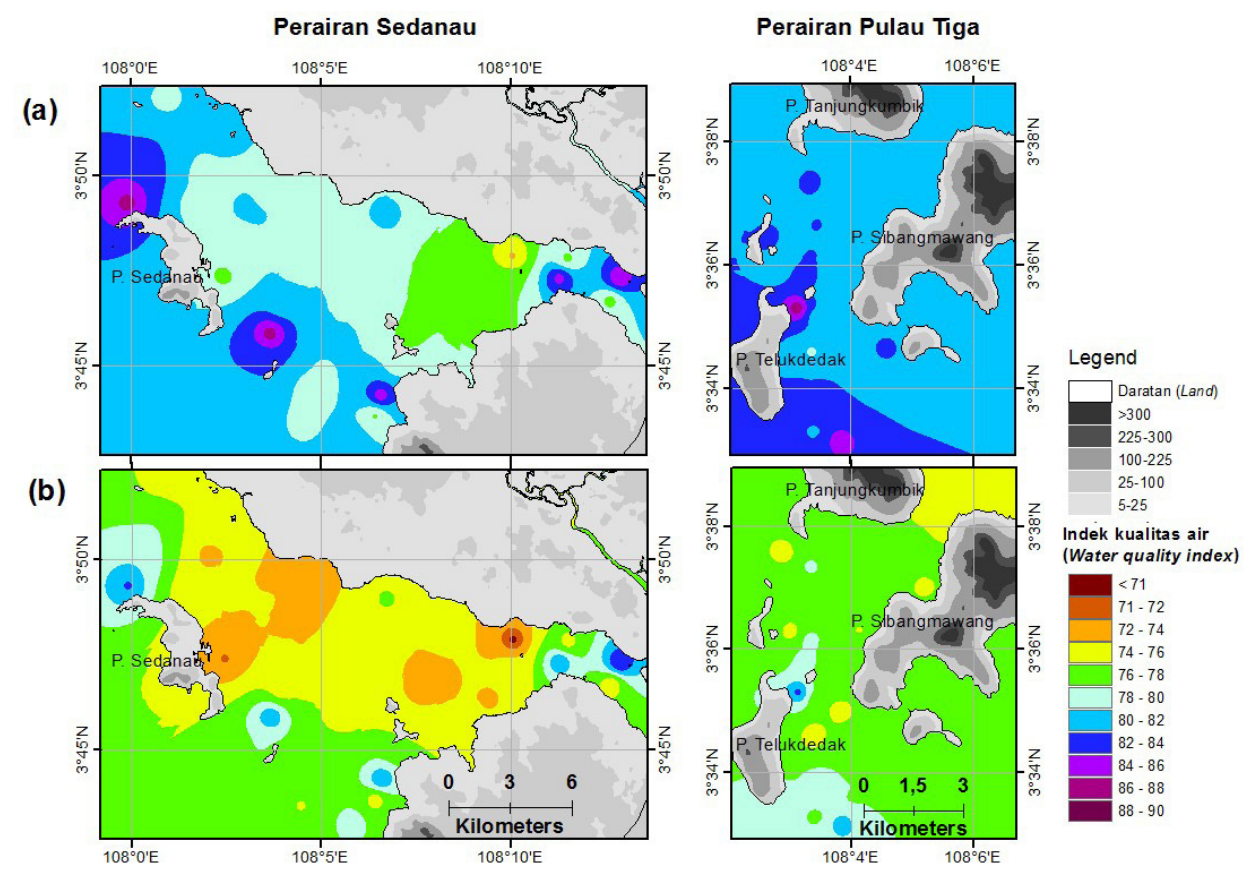

Gambar 4. Sebaran spasial indek kualitas air di perairan Sedanau dan Pulau Tiga Kabupaten Natuna, Kepulauan Riau: (a) WQI Obj dan (b) WQI min.

nutrien tersebut sangat erat kaitannya dengan lokasi pengamatan (dekat darat atau lokasi terbuka). Kondisi nutrien dan keterlindungan kawasan ini sangat penting dalam pengembangan budi daya laut (ikan dan rumput laut). Kawasan yang terbuka dengan kondisi gelombang yang besar $(>60 \mathrm{~cm} / \mathrm{s})$ merupakan kawasan yang tidak sesuai untuk pengembangan budi daya ikan laut (Beveridge, 2004; Pérez et al., 2005). Berdasarkan hasil analisis CA ini, kawasan dengan kategori klaster 1 dan 2 dapat direkomendasikan untuk pengembangan budi daya ikan laut dan rumput laut. Pendekatan CA juga telah digunakan oleh Radiarta
\& Erlania (2015b) untuk pengembangan budi daya rumput laut yaitu melalui analisis spasial berdasarkan karaktreristik stasiun pengamatan dan analisis temporal berdasarkan waktu (bulan) pengamatan; hasil analisis tersebut kemudian dihubungkan dengan tingkat kesesuaian lahan dan kesesuaian musim tanam budi daya rumput laut di Teluk Gerupuk, Lombok.

\section{Indeks Kualitas Perairan}

Indeks kualitas perairan (WQI) banyak digunakan untuk menginterpretasikan data kualitas air yang

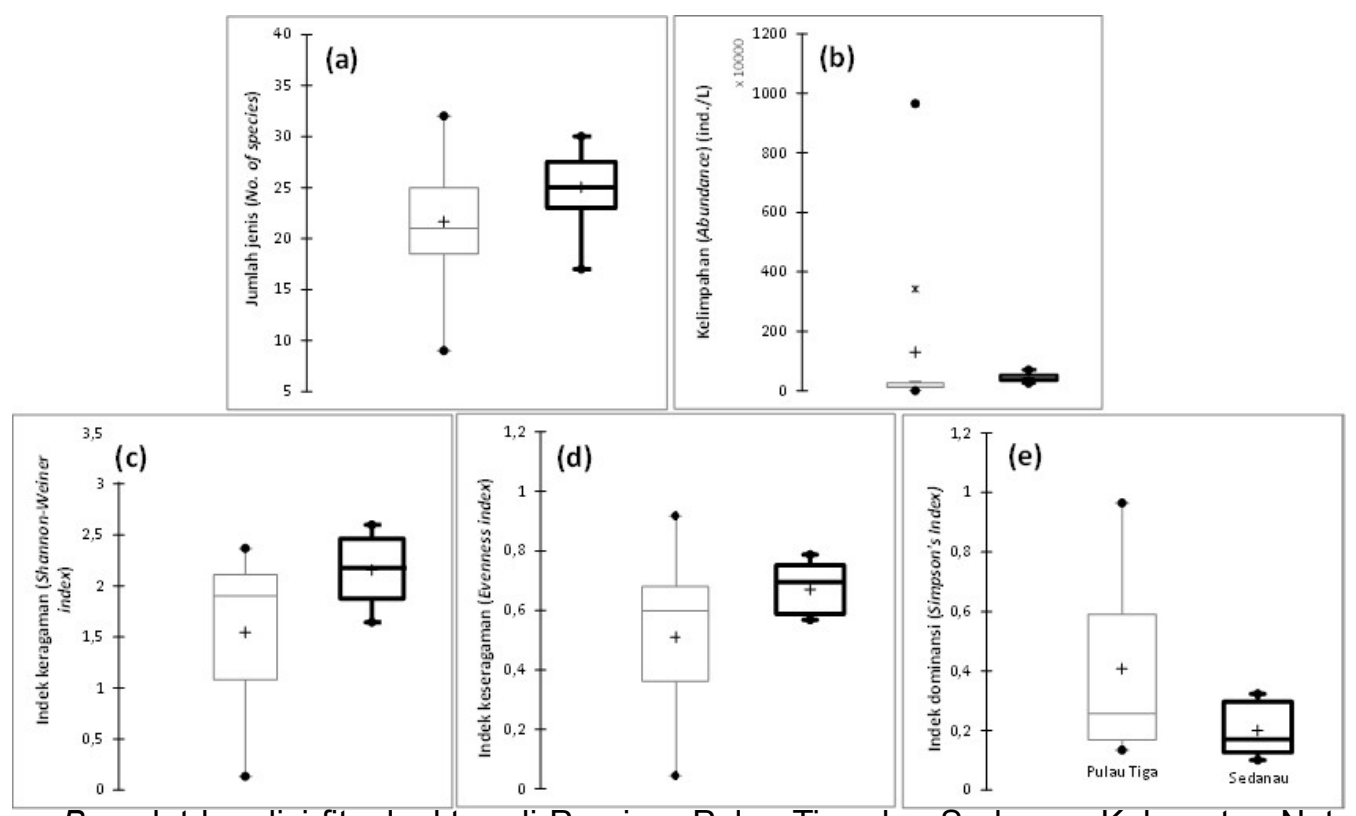

Gambar 5. Box plot kondisi fitoplankton di Perairan Pulau Tiga dan Sedanau, Kabupaten Natuna Provinsi Kepulauan Riau: (a) jumlah jenis, (b) kelimpahan, (c) indek keragaman, (d) indek keseragaman, dan (e) indek dominansi. 


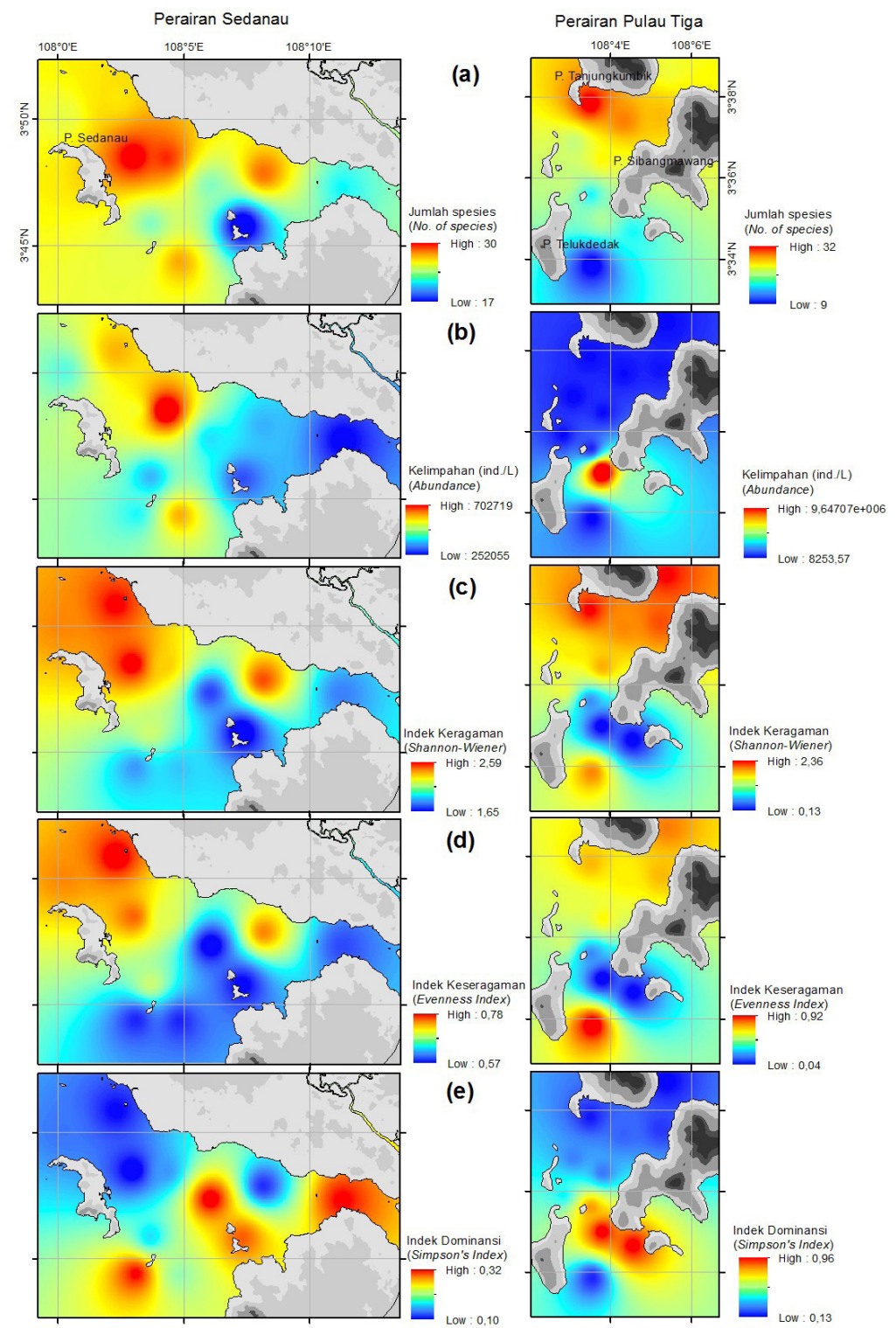

Gambar 6. Sebaran spasial kondisi fitoplankton di Perairan Sedanau dan Pulau Tiga, Kabupaten Natuna Provinsi Kelupauan Riau: (a) jumlah jenis, (b) kelimpahan, (c) indek keragaman, (d) indek keseragaman, dan (e) indek dominansi.

komplek menjadi sederhana (misalnya: sangat baik, baik, sedang, buruk, dan sangat buruk) sehingga dapat membantu dalam perencanaan dan pengelolaannya. WQI dapat juga digunakan sebagai alat untuk membandingkan kondisi kualitas air dari berbagai sumber, sehingga dapat memberikan gambaran tentang kemungkinan masalah dalam pengelolaan kawasan tertentu (Muthulakshmi et al., 2013).

Hasil analisa $W Q_{o b j}$ dengan menggunakan seluruh parameter yang dikumpulkan dari lapangan (Tabel 1), menunjukkan kisaran nilai indeks antara 74-90 (Gambar 4), dan termasuk dalam kategori baik. Sebaran spasial $W{ }_{o b j}$ di Perairan Sedanau memiliki kisaran indeks yang lebih bervariasi dibandingkan dengan Pulau Tiga. Umumnya nilai indeks yang lebih kecil ditemukan pada kawasan di dalam teluk atau dekat daratan utama. Hal ini dapat disebabkan oleh adanya pengaruh aktivitas di daratan (pemukiman dan perkebunan) yang menyebabkan rendahnya kondisi kualitas perairan sekitar kawasan tersebut. Kawasan dalam teluk di Perairan Sedanau terhubung dengan aliran sungai dan merupakan lokasi pelabuhan kapal penyebaran antara Pulau Bunguran dan Sedanau. Sedangkan kawasan daratan utama di Pulau Tiga merupakan daerah industri pertamina.

Perairan Pulau Sedanau dan Pulau Tiga merupakan kawasan pengembangan minapolitan untuk budi daya laut (ikan dan rumput laut), pemilihan parameter kunci biota budi daya (suhu, $\mathrm{pH}$, kekeruhan, $\mathrm{DO}, \mathrm{NH}_{4}$ ) juga telah dianalisis melalui perhitungan $W I_{\text {min }}$. Hasil perhitungan $W Q I_{\text {min }}$ menunjukkan nilai indeks yang lebih rendah dari $\mathrm{WQI}_{\text {obj }}$ yaitu berkisar antara 71-84 (Gambar 4), namun kisaran tersebut masih masuk dalam kategori baik (Koçer et al., 2014). 
Pola distribusi spasial $\mathrm{WQI}_{\min }$ yang ditemukan juga

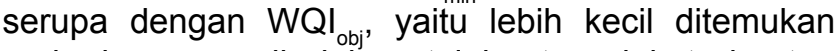
pada kawasan di dalam teluk atau dekat daratan utama. Kecendrungan hasil perhitungan WQI ${ }_{\text {min }}$ yang lebih rendah dengan $\mathrm{WQI}_{\mathrm{obj}}$ juga diperoleh dari hasil penelitian Koçer et al. (2014).

Hasil perhitungan $W \mathrm{I}_{\text {obj }}$ dan $\mathrm{WQI}_{\text {min }}$ di kedua lokasi penelitian menunjukkan bahwa perairan Pulau Tiga memiliki kondisi lebih baik dengan nilai indeks yang lebih tinggi dan tersebar lebih merata dibandingkan dengan perairan Sedanau (Gambar 4). Pola sebaran spasial nilai WQI ini secara umum mengikuti pola pembagian kawasan berdasarkan analisa klaster (Gambar 3). Klaster 1 memiliki nilia indeks yang lebih rendah dibandingkan dengan klaster 2 dan 3 (Gambar 3 dan 4). Hal ini menunjukkan bahwa analisa klaster yang dilakukan dalam penelitian ini selain dapat memberikan gambaran secara umum tentang keterlindungan kawasan juga dapat merepresentasikan sebaran WQI perairan.

\section{Kondisi Fitoplankton}

Jumlah jenis, kelimpahan dan indeks biologi fitoplankton di Perairan Pulau Tiga lebih bervariasi dibandingkan dengan Perairan Sedanau (Gambar 5). Secara umum kelimpahan fitoplankton di perairan Pulau Tiga (8.204 - 319.264 ind./L) lebih rendah dibandingkan di kawasan perairan Pulau Sedanau (252.051 - 702.772 ind./L), kecuali pada dua stasiun yang terdapat di bagian selatan Pulau Lagong (salah satu pulau di kawasan Pulau Tiga), dimana pada kedua stasiun pengamatan tersebut ditemukan kelimpahan jenis Trichodesmium $s p$ yang sangat tinggi, yaitu 9.649.504 dan 3.417.963 ind./L (Gambar 5b). Kelimpahan spesies yang tinggi ini diindikasikan oleh kelimpahan nutrient yang tinggi terutama $\mathrm{N}$ total dan nitrat $\left(\mathrm{NO}_{3-} \mathrm{N}\right)$. Hal ini memperlihatkan bahwa pada area kedua stasiun pengamatan terdapat dominansi ekosistem oleh spesies tertentu; yang juga ditunjukkan oleh tingginya Indekss Dominansi (D) pada kedua stasiun tersebut (Gambar 5e). Menurut Devassy (1984) dalam (Adnan, 1985), blooming Trichodesmium tidak membahayakan perairan, tetapi justru dapat memperbaiki siklus nutrien di perairan. Adnan (1985) juga menyatakan bahwa akibat dari ledakan jenis ini perairan akan menjadi subur, tetapi bila terjadi di dekat pantai terutama di daerah karang maka pembusukan dari gumpalan fitoplankton ini akan berakibat mematikan karang karena akan mengurangi oksigen terlarut di perairan.

Jumlah jenis fitoplankton di perairan Pulau Tiga dan Pulau Sedanau memperlihatkan nilai yang bervariasi. Kisaran jumlah jenis fitoplankton yang ditemukan di perairan Pulau Tiga berkisar 9 - 32 jenis; dan di perairan Pulau Sedanau sekitar 17 - 30 jenis (Gambar 5). Indekss Keragaman ( $\mathrm{H}^{\prime}$ ) fitoplankton di perairan Pulau Tiga dan Pulau Sedanau $(1<\mathrm{H}<3)$, mengindikasikan bahwa kondisi kedua perairan tergolong berada pada kondisi dengan stabilitas moderat, dimana kondisi ini memperlihatkan kemungkinan terdapatnya gangguan faktor lingkungan pada perairan tersebut (Basmi, 2000). Indekss keseragaman (E) dengan nilai mendekati 1 memperlihatkan keseragaman antar spesies fitoplankton yang tinggi, menunjukkan bahwa tingkat kelimpahan antar spesies tidak jauh berbeda sehingga kondisi ekosistem perairan menjadi stabil. Selain itu, indekss dominansi dengan nilai $D$ yang

Tabel 3 .

Hubungan antara kondisi kualitas air dengan fitoplankton di Perairan Sedanau dan Pulau Tiga, Kabupaten Natuna Provinsi Kepulauan Riau.

\begin{tabular}{|c|c|c|c|c|c|c|c|}
\hline Variables & $W \mathbf{I}_{\text {obj }}$ & $\mathbf{W Q} \mathbf{I}_{\min }$ & F-Jenis & Fkelimpahan & $\mathbf{F}-\mathbf{H}$ & F-E & F-D \\
\hline \multicolumn{8}{|c|}{ Pulau Sedanau } \\
\hline $\begin{array}{l}\text { Klaster } \\
\text { WQI }_{\text {obj }} \\
\text { WQI }_{\text {min }} \\
\text { F-Jenis } \\
\text { Fkelimpahan } \\
\text { F-H } \\
\text { F-E }\end{array}$ & 0,29 & $\begin{array}{l}-0,14 \\
\mathbf{0 , 7 4}\end{array}$ & $\begin{array}{l}0,45 \\
-0,33 \\
-\mathbf{0 , 5 5}\end{array}$ & $\begin{array}{l}0,70 \\
-0,13 \\
-0,44 \\
\mathbf{0 , 7 2}\end{array}$ & $\begin{array}{l}\mathbf{0 , 6 2} \\
0,01 \\
-0,31 \\
\mathbf{0 , 7 9} \\
0,50\end{array}$ & $\begin{array}{l}\mathbf{0 , 5 8} \\
0,18 \\
-0,21 \\
\mathbf{0 , 5 9} \\
0,35 \\
0,94\end{array}$ & $\begin{array}{l}-0,51 \\
0,16 \\
0,42 \\
-\mathbf{0 , 6 9} \\
-0,40 \\
-0,94 \\
-0,91\end{array}$ \\
\hline \multicolumn{8}{|l|}{ Pulau Tiga } \\
\hline $\begin{array}{l}\text { Klaster } \\
\text { WQI }{ }_{\text {obj }} \\
\text { WQI }_{\text {min }} \\
\text { F-Jenis } \\
\text { Fkelimpahan } \\
\text { F-H } \\
\text { F-E }\end{array}$ & 0,44 & $\begin{array}{l}0,51 \\
0,90\end{array}$ & $\begin{array}{l}-\mathbf{0 , 8 7} \\
-0,19 \\
-0,31\end{array}$ & $\begin{array}{l}0,05 \\
-0,30 \\
-0,09 \\
-0,06\end{array}$ & $\begin{array}{l}-\mathbf{0 , 7 2} \\
0,05 \\
-0,05 \\
\mathbf{0 , 7 0} \\
-0,53\end{array}$ & $\begin{array}{l}-0,41 \\
0,21 \\
0,14 \\
0,37 \\
-0,71 \\
\mathbf{0 , 9 0}\end{array}$ & $\begin{array}{l}\mathbf{0 , 5 6} \\
-0,09 \\
-0,01 \\
-0,51 \\
\mathbf{0 , 6 5} \\
-\mathbf{0 , 9 6} \\
-\mathbf{0 , 9 7}\end{array}$ \\
\hline
\end{tabular}

Angka dengan warna gelap menunjukkan tingkat signifikan pada level 0,1 (90\%) 
umumnya mendekati 0 memperlihatkan bahwa secara umum tidak terdapat dominansi spesies tertentu; kecuali pada dua stasiun bagian selatan Pulau Lagong (salah satu pulau di kawasan Pulau Tiga; Gambar 6e).

Distribusi spasial jumlah jenis, kelimpahan dan indeks biologi fitoplankton di Perairan Sedanau dan Pulau Tiga ditampilkan pada Gambar 6. Di Perairan Sedanau sebaran nilai jumlah jenis, kelimpahan dan indeks biologi (keragaman dan keseragaman) fitoplankton yang tinggi umumnya terletak di luar kawasan; kecuali indeks dominasi yang memiliki nilai tertinggi tersebar di bagian dalam teluk (Gambar 6e) Kawasan dengan nilai yang tinggi ini merepresentasikan klaster 3 (Gambar 3), dan kawasan dengan nilia WQI yang tinggi (Gambar 4). Sebaran spasial fitoplankton di Perairan Pulau Tiga menunjukkan bahwa nilai jumlah jenis dan indeks biologi (keragaman dan keseragaman) yang tinggi tersebar di kawasan dekat daratan utama. Kondisi ini merepresentasikan kawasan klaster 1 (Gambar 3) dengan nilai WQI yang relatif lebih rendah (Gambar 4). Hasil yang diperoleh dari dua lokasi penelitian ini menunjukkan karakteristik kawasan yang cukup berbeda baik secara geografis maupun biofisik kawasan. Perairan di sekitar Pulau Tiga merupakan perairan yang relatif jernih dan dangkal, serta banyak ditemukan sebaran terumbu karang di dasar perairan. Sementara itu, di kawasan perairan Pulau Sedanau terdapat lokasi-lokasi dimana kekeruhan perairan tinggi dan dasar berlumpur, yang disebabkan adanya masukan bahan organik yang terbawa oleh aliran sungai dari daratan. Kondisi ini akan berpengaruh terhadap kelimpahan dan distribusi (spasial) fitoplankton (Xu et al., 2017).

\section{Hubungan Kondisi Kualitas Air dengan Fitoplankton}

Pada penelitian ini, analisis kondisi perairan yang meliputi $C A, W \mathrm{~W}_{\text {obj, }}$, dan $\mathrm{WQ}_{\text {min }}$ digunakan untuk melihat hubungannya dengan kondisi plankton, yang meliputi jumlah jenis, kelimpahan dan indeks biologi (Tabel 3).

Terdapat hubungan yang erat (level signifikan $90 \%$ ) antara pembagian kawasan (klaster) dengan kondisi fitoplankton. Pembagian kawasan di Perairan Sedanau berhubungan secara positif dengan kelimpahan, indeks keragaman, dan indeks kesegaraman fitoplankton; sedangkan di Perairan Pulau Tiga berhubungan secara negatif (terbalik) dengan kelimpahan dan indeks keragaman (Tabel 3). Secara jelas hubungan tersebut digambarkan melalui sebaran spasial masing-masing parameter (Gambar 3 dan 6).

Hubungan WQI dengan fitoplankton di kedua lokasi penelitian tidak ditemukan secara signifikan, hanya $\mathrm{WQI}_{\min }$ yang ditemukan hubungannya dengan jumlah jenis fitoplankton di Perairan Sedanau. Selain itu terdapat hubungan yang erat antara dua WQI yang digunakan dalam penelitian ini baik untuk Perairan Sedanau $(0,74)$ dan Perairan Pulau Tiga $(0,90)$. Hasil ini menunjukkan bahwa pemanfaatan WQI tidak dapat digunakan secara langsung untuk melihat kondisi fitoplankton pada suatu kawasan perairan, namun lebih pada menggambarkan kondisi perairan secara umum. Namun sebaliknya kondisi fitoplankton dapat digunakan sebagai indikator ekologi perairan untuk menduga tingkat tropik suatu perairan (Yang et al., 2016) dan indikator tingkat kesuburan perairan (Karydis \& Tsirtsis, 1996).

Terdapat hubungan yang signifikan (90\%) antara indeks keragaman dan keseragaman di dua lokasi penelitian. Hal serupa juga dijelaskan oleh Gao \& Song (2005), bahwa umumnya terdapat hubungan yang positif antara indeks keragaman dengan indeks keseragaman fitoplankton. Adanya perubahan proses ekologi yang terjadi pada suatu kawasan meliputi kompetisi dan pemangsaan dapat mempengaruhi nilai indeks keragaman. Selain itu adanya variabilitas iklim (El-nino dan La-nina) dapat mempengaruhi distribusi dan komposisi fitoplankton yang terdapat dalam perairan (Richardson \& Schoeman, 2004).

\section{KESIMPULAN}

Perairan Pulau Sedanau dan Pulau Tiga merupakan kawasan pengembangan budi daya laut (ikan dan rumput laut). Kondisi lingkungan perairan sangat penting guna mendukung pengembangan budi daya laut tersebut. Hasil penelitian ini menunjukkan bahwa kondisi perairan di Pulau Sedanau dan Pulau Tiga sangat mendukung aktivitas budi daya laut yang dicirikan dengan nilai WQI yang masuk kategori baik (71 - 90). Namun nilia WQI tersebut tidak secara signifikan berhubungan dengan kondisi fitoplankton. Berdasarkan analisa klaster telah membagi kedua lokasi penelitian menjadi tiga klaster. Ketiga klaster tersebut merepresentasikan keterlindungan lokasi dan kesuburan perairan serta kedekatan lokasi dengan daratan yang diindikasikan dengan kondisi fitoplankton. Hasil penelitian ini dapat dijadikan dasar dalam melakukan desain pemantauan kualitas air secara berkelanjutan guna mendukung pengembangan budi daya laut.

\section{PERSANTUNAN}

Penulis mengucapkan terima kasih kepada Dinas Kelautan dan Perikanan Kabupaten Natuna atas bantuannya selama kegiatan lapangan. Kami mengucapkan terima kasih kepada Prof. I.N Adiasmara Giri, Aulia Ranggi Pamalik, Bnadi Sarah Ayutyas yang telah membantu kelancaran pengumpulan 
data lapangan. Penelitian ini merupakan bagian dari penelitian Analisa Kebijakan Pengembangan Marikultur Pusat Penelitian dan Pengembangan Perikanan Budi Daya T.A 2015.

\section{DAFTAR PUSTAKA}

Adnan, Q. (1985). Red Tide. Oseana, 10(2): 48-55.

APHA (American Public Health Association). (2012). Rice, E.W., Baird, R.B., Eaton, A.D., Clesceri, L.S. (eds). Standard Methods for The Examination of Water and Wastewater. 22nd Edition. Washington D.C.: American Public Health Association, American Water Works Association (AWWA), Water Environment Federation. p.1496.

APHA (American Public Health Association). (1989). Standard Methods for the Examination of Water and Waste Water Including Bottom Sediment and Sludges. 17th ed. Amer. Publ. Health Association Inc., New York. p. 1527.

Basmi, J. (2000). Planktonologi: plankton sebagai bioindikator kualitas perairan. Institut Pertanian Bogor. 60 hal.

Bayo, J., \& opez-Castellanos, J.L. (2016). Principal factor and hierarchical cluster analyses for the performance assessment of an urban wastewater treatment plant in the Southeast of Spain. Chemosphere, 155: 152-162.

Beveridge, M.C.M. (2004). Cage Aquaculture (Eds. 3rd). Blackwell Publishing Ltd. p. 377.

Butler, E.C.V., Blackburn, S.I., Clementson, A.A., Morgan, P.P., Parslow, J.S. \& Volkman, J.K. (2001). A survey strategy and environmental monitoring network for an estuary supporting finfish cage culture. ICES Journal of Marinene Science 58: 460-468.

Clark, W.A.V. \& P.L. Hosking. (1986). Statistical Methods for Geographers. John Wiley \& Sons, Inc. p. 513.

Ditjen KP3K (Direktorat Jenderal Kelautan, Pesisir dan Pulau-Pulau Kecil). (2015). Pengembangan Kawasan Kelautan dan Perikanan Terintegrasi di Kabupaten Natuna. Direktorat Jenderal Kelautan, Pesisir dan Pulau-Pulau Kecil. Kementerian Kelautan dan Perikanan. 184 hal.

DKP (Dinas Kelautan dan Perikanan) Natuna. (2011). Rencana strategis (RENSTRA) Dinas Kelautan dan Perikanan Kabupaten Natuna 2011-2016.
Dinas Kelautan dan Perikanan Kabupaten Natuna. 68 hal.

Gao, X. \& Song, J. (2005). Phytoplankton distribution and their relationship with the environment in the Cahngjiang Estuary, China. Marine Pollution Bulletin, 50: 327-335.

Huang, J., Ho, M. \& Du, P. (2011). Assessment of temporal and spatial variation of coastal water quality and source identification along Macau peninsula. Stoch Environ Res Risk Assess 25: 353-361.

Karydis, M. \& Tsirtsis, G. (1996). Ecological indeces: a biometric approach for assessing eutropication levels in the marine environment. The Science of the Environment, 186: 209-219.

Kamble, S.R. \& Vijay, R. (2011). Assessment of water quality using cluster analysis in coastal region of Mumbai, India. Environ. Monit. Assess. 178: 321332.

Kannel, P.R., Lee, S., Lee, Y.S., Kanel, S.R. \& Khan, S.P. (2007). Application of Water Quality Indices and dissolved oxygen as indicators for river water classification and urban impact assessment. Environ. Monit. Assess., 132: 93-110.

KLH (Kementerian Lingkungan Hidup). (2004). Keputusan Menteri Negara Kependudukan dan Lingkungan Hidup No. 51 tahun 2004, tanggal 8 April 2004 tentang baku mutu air laut. Kementerian Lingkungan Hidup. Jakarta. 11 hal.

Koçer, M.A. \& Sevgili, H. (2014). Parameters selection for water quality index in the assessment of the environmental impacts of land-based trout farms. Ecological Indicators, 36: 672-681.

Lobato, T.C., Hauser-Davis, R.A., Oliveira, T.F., Silveira, A.M., Silva, H.A.N., Tavares, M.R.M. \& Saraiva, A.C.F. (2015). Construction of a novel water quality index and quality indicator for reservoir water quality evaluation: A case study in the Amazon region. Journal of Hydrology, 522: 674683.

Mujiyanto, Tjahjo, D.W.H. \& Sugianti, Y. (2011). Hubungan antara kelimpahan fitoplankton dengan konsentrasi $\mathrm{N}: \mathrm{P}$ pada daerah keramba jaring apung (KJA) di Waduk Ir. H. Djuanda. Limnotek, 18: 15-25.

Muthulakshmi, A.L., Natesan, U.,Deepthi, K., Ferre,V.A., Venugopalan, V.P. \& Narasimhan, S.V. (2013). Assessment of water quality through indeces 
around Kalpakkam, southeast coast of India. Arch. Environ, Sci., 7: 23-32.

Nontji, A. (2008). Plankton laut. Pusat Penelitian Oseanografi. Lembaga IImu Pengetahuan Indonesia (LIPI). LIPI Press. 331 hal.

Odum, E.P. (1971). Fundamentals of Ecology. Third edition. W.B. Saunders Company, Philadelphia, London, Toronto. p. 574.

Pérez, O.M., Telfer, T.C. \& Ross, L.G. (2005). Geographical information system-based models for offshore floating marine fish cage aquaculture site selection in Tenerife, Canary Islands. Aquaculture Research, 36: 946-961.

Phung, D., Huang, S., Rutherford, S., Dwirahmadi, F., Chu, C., Wang, X., Nguyen,M., Nguyen, N.H., Do,C.M., Nguyen, T.H. \& Dinh. T.A.D. (2015). Temporal and spatial assessment of river surface water quality using multivariate statistical techniques: a study in Can Tho City, a Mekong Delta area, Vietnam. Environ Monit Assess, 187: 229.

Pomeroy, R., Agbayani, R., Toledo, J., Sugama, K., Slamet, B. \& Tridjoko. (2002). The Status of Grouper Culture in Southeast Asia. Financial Feasibility Analysis for Grouper Culture Systems in the Philippines and Indonesia. Draft Chapter 6. In: Pomeroy, R., Parks, J., Balboa, C. (eds.). Farming the Reef: A State-of-the-Art Review of Aquaculture of Coral Reef Organisms in Tropical Nearshore Environments. World Resources Institute, Washington DC.

Radiarta, I.N. \& Erlania. (2015). Indeks kualitas air dan sebaran nutrien sekitar budi daya laut terintegrasi di perairan Teluk Ekas, Nusa Tenggara Barat: aspek penting budi daya rumput laut. Jurnal Riset Akuakultur, 10 (1): 141-152.

Radiarta, I.N. \& Erlania. (2015b). Analisis spasial dan temporal kondisi kualitas perairan melalui pendekatan statistik multivariat di Teluk Gerupuk Provinsi Nusa Tenggara Barat. Jurnal Riset Akuakultur, 10 (3): 435-447.

Radiarta, I N., Erlania, Sugama, K., Yudha, H.T. \& Wada, M. (2014). Frequent monitoring of water temperature in Pegametan Bay,Bali: a preliminary assessment towards management of marine aquaculture development. Indonesian Aquaculture Journal, 9 (2): 185-193.

Rahayu, Y.P., Adi, R.A., Priyambodo, D.G., Puspita, C.D. \& Triwibowo, H. (2016). Kualitas air permukaan dan sebaran sedimen dasar perairan Sedanau,Natuna, Kepulauan Riau. Jurnal Segara, 12 (1): 53-63.

Razmkhah, H., Abrishamchi, A. \& Torkian, A. (2010). Evaluation of spatial and temporal variation in water quality by pattern recognation techniques: a case study on Jajrood River (Tehran, Iran). Journal of Enviromental Management, 91: 852860.

Richardson, A.J. \& Schoeman, D.S. (2004). Climate Impact on Plankton Ecosystems in the Northeast Atlantic. Science, 305 (5690): 1609-1612.

Sadovy, Y. (2000). Regional survey for fry/fingerling supply and current practices for grouper mariculture: Evaluating current status and long-term prospects for grouper mariculture in Southeast Asia. Final report to the collaborative APEC Grouper Research and Development Network (FWG 01/99).

Sánchez, E., Colmenarejo, M.F., Vicente, J., Rubio, A., Garcıá, M.G., Travieso. \& Borja, R. (2007). Use of the water quality index and dissolved oxygen deficit as simple indicators of watersheds pollution. Ecological Indicators, 7: 315-328.

Simões, F.D.S., Moreira, A.B., Bisinoti, M.C., Gimenez, S.M.N. \& Yabe, M.J.S. (2008). Water quality index as a simple indicator of aquaculture effects on aquatic bodies. Ecological Indicators, 8: 476-484.

Xu, Y., Li, A.J., Qin, J., Li, Q., Ho, J.G. \& Li, H. (2017). Seasonal patterns of water quality and phytoplankton dynamics in surface waters in Guangzhou and Foshan, China. Science of the Total Environment. (Article in press).

Yang, B., Jiang, Y-J., He, W., Liu, W-X., Kong, X-Z., Jørgensen, S.E. \& Xu, F-L. (2016). The tempospatial variations of phytoplankton diversities and their correlation with trophic state levels in a large eutrophic Chinese lake. Ecological Indicators, 66: 153-162. 